\title{
Effect of hyperbaric oxygen on hyperglycemia-induced cochlear damage: An experimental study
}

\section{Hiperbarik oksijenin hiperglisemiye bağhl koklear hasar üzerine etkisi: Deneysel bir çalışma}

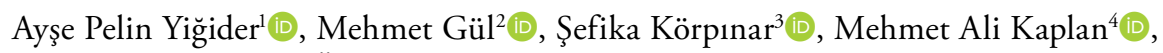 \\ Ela Server ${ }^{1}\left(\mathbb{D}\right.$, Özgür Yiğit ${ }^{1}$ (D), Sevgi Daştan ${ }^{5}$ (D), Akın Savaş Toklu ${ }^{4}(\mathbb{D}$ \\ ${ }^{1}$ Department of Otolaryngology, İstanbul Training and Research Hospital, İstanbul, Turkey \\ ${ }^{2}$ Department of Histology and Embryology, Medicine Faculty of İnönü University, Malatya, Turkey \\ ${ }^{3}$ Medok Hyperbaric Oxygen Treatment Center, İstanbul, Turkey \\ ${ }^{4}$ Department of Underwater and Hyperbaric Medicine, İstanbul University, İstanbul Faculty of Medicine, İstanbul, Turkey \\ ${ }^{5}$ Faculty of Veterinary Medicine, Cumhuriyet University, Sivas, Turkey
}

\begin{abstract}
Objectives: This study aims to investigate whether hyperglycemiainduced cochlear damage can be treated with hyperbaric oxygen therapy (HBOT) in rats with diabetes mellitus using distortion product otoacoustic emission (DPOAE) and histopathological analysis.

Materials and Methods: The study included 18 male albino Sprague Dawley rats (weighing $\geq 350 \mathrm{~g}$, at least two months of age). Animals were divided into three groups as the control group (group 1), streptozocin (STZ)-induced diabetes group (group 2), and STZ-induced diabetes+HBOT group (group 3). Distortion product otoacoustic emission was used to demonstrate functional status of cochlea and applied at the beginning and at the end of the eighth week. Group 3 was treated with HBOT for one week at sixth week. By the end of the eighth week, all animals were decapitated. Histological evaluation was performed under light microscopy.

Results: All animals in groups 2 and 3 had fasting blood glucose levels $>250 \mathrm{mg} / \mathrm{dL}$. There was no difference in terms of signal-to-noise ratio values between groups at the end of the study except for $2 \mathrm{kHz}$, which was lower in groups 2 and 3. Histological evaluation showed that degenerations including hydropic degeneration, loss of supporting and hair cells, basilar membrane deformation, and fibrinoid material in deposition in the scala media were higher in group 2 than group 3. Conclusion: In our study, HBOT ameliorated diabetes-induced cochlear damage histologically. In light of our findings, we believe that the management of hearing loss in diabetics may evolve dramatically if the proper algorithm is formed.
\end{abstract}

Keywords: Cochlea, diabetes mellitus, distortion product otoacoustic emission, hyperbaric oxygen.
$\ddot{O} Z$

Amaç: Bu çalışmada diabetes mellituslu sıçanlarda hiperglisemiye bağlı koklear hasarın hiperbarik oksijen terapisi (HBOT) ile tedavi edilip edilemeyeceği distorsiyon ürünü otoakustik emisyon (DÜOAE) ve histopatolojik analiz kullanılarak araştırıldı.

Gereç ve Yöntemler: Çalışmaya 18 erkek albino Sprague Dawley sıçan ( $\geq 350 \mathrm{~g}$ ağırlığında, en az iki aylık) dahil edildi. Hayvanlar kontrol grubu (grup 1), streptozosin (STZ) ile indüklenmiş diyabet grubu (grup 2) ve STZ ile indüklenmiş diyabet+HBOT grubu (grup 3) olmak üzere üç gruba ayrıldı. Kokleanın fonksiyonel durumunu göstermek için başlangıçta ve sekizinci haftanın sonunda DÜOAE kullanıldı. Grup 3 altıncı haftada bir hafta boyunca HBOT ile tedavi edildi. Sekizinci haftanın sonunda tüm hayvanlar dekapite edildi. Histolojik değerlendirme ışık mikroskopisi altında yapıldı.

Bulgular: Grup 2 ve 3 'teki tüm hayvanlarda açlık kan şekeri > 250 mg/ dL idi. Çalışmanın sonunda sinyal gürültü oranı değerleri açısından gruplar arasında $2 \mathrm{kHz}$ 'in grup 2 ve 3 'te daha düşük olması dışında farklılık yoktu. Histolojik değerlendirme hidropik dejenerasyon, destek ve saç hücrelerinde kayıp, baziler membran deformasyonu ve skala mediada fibrinoid materyal birikimi dahil dejenerasyonların grup 2'de grup 3'ten daha yüksek olduğunu gösterdi.

Sonuç: Çalışmamızda HBOT diyabete bağlı koklear hasarı histolojik olarak azalttı. Bulgularımız ışığında, eğer doğru algoritma oluşturulabilirse diyabetiklerde işitme kaybının tedavisi önemli ölçüde gelişebilir.

Anahtar sözcükler: Koklea, diabetes mellitus, distorsiyon ürünü otoakustik emisyon, hiperbarik oksijen.

Received: January 01, 2019 Accepted: March 02, 2019 Published online: March 28, 2019

Correspondence: Ayşe Pelin Yiğider, MD. İstanbul Eğitim ve Araştırma Hastanesi Kulak Burun Boğaz Hastalıkları Kliniği, 34098 Fatih, İstanbul, Turkey. e-mail: pelin.gor@gmail.com

\section{Citation:}

Yiğider AP, Gül M, Körpınar Ş, Kaplan MA, Server E, Yiğit Ö, et al. Effect of hyperbaric oxygen on hyperglycemia-induced cochlear damage: An experimental study. KBB Uygulamaları 2019;7(2):71-79. 
Diabetes mellitus is a chronic disease characterized by hyperglycemia, which can result in severe conditions, such as vascular disorders, neuropathy and sensory loss if blood sugar level cannot be controlled. ${ }^{[1]}$ Diabetic patients are prone to developing hearing loss because of direct cochlear damage, microvascular dysfunction and hyperglycemia-induced neuropathy. ${ }^{[2]}$ Diabetesinduced damage occurs at the cellular level in the cochlea and microvascular angiopathy causes damage at stria vascularis. ${ }^{[3]}$ Dysfunctional glucose metabolism is associated with the early involvement of cochlear hair cells and neuronal pathways, namely type 1 and type 2 fibers, spiral ganglia and ascending auditory. ${ }^{[4]}$ Owing to the increasing prevalence of diabetes, hyperglycemiainduced audiovestibular dysfunction is estimated to increase in the near future. ${ }^{[5]}$

Otoacoustic emissions are sounds that travel backwards in the ear canal. They originate in the cochlear outer hair cells. The apical movement of travelling sound waves interacts with these backward travelling emissions and generates distortions as a result of cochlear nonlinearity. The amplitude of emissions provides an estimate of cochlear amplification. ${ }^{[6]}$ Sockalingam et al. ${ }^{[7]}$ reported that transient and distortion product otoacoustic emissions (DPOAEs) are sensitive methods for evaluating the functional status of outer hair cells.

Distortion product otoacoustic emissions are evoked products of cochlear outer hair cells. They are reproducible and negatively affected by damage to outer hair cells. DPOAE measurements are useful for assessing cochlear damage, including ototoxicity. DPOAEs result from two-tone stimuli and provide information at different frequencies. ${ }^{[8]}$ Thus diabetesinduced cochlear damage can be demonstrated by DPOAEs in a frequency specific manner. Simoncelli et al. ${ }^{[9]}$ reported that the intensity and amplitude of DPOAEs are smaller in diabetics than in healthy individuals.

The effects of diabetes on hearing have been investigated in animal models by using diabetogenic drugs (alloxan or streptozocin [STZ]) and genetic modifications. After electrophysiological dysfunction was successfully demonstrated in an animal model of diabetes, an increased number of studies have focused on the treatment of diabetes-induced complications. ${ }^{[10,11]}$

Hyperbaric oxygen $\left(\mathrm{HBO}_{2}\right)$ therapy (HBOT), the inhalation of $100 \%$ oxygen at pressures higher than atmospheric pressure (between 1 and 2.8 atmosphere absolute [ATA]), is used for the treatment of various diseases since hypoxia can be reversed by $\mathrm{HBO}_{2}$ in certain conditions. Recent studies have shown that increased oxygen tension by $\mathrm{HBO}_{2}$ prevents the adverse effects of ischemia and accelerates healing in different types of wounds including diabetic foot ulcers. Hyperbaric oxygen may increase oxygenation in perilymph as well, therefore it is recommended for the treatment of sudden idiopathic sensorineural hearing loss. ${ }^{[12]}$ Hyperbaric oxygen is a well-established treatment method for several diseases such as carbon monoxide poisoning, decompression sickness, arterial gas embolism and acute traumatic ischemias. ${ }^{[13,14]}$ In this study, we aimed to investigate whether hyperglycemiainduced cochlear damage can be treated with HBOT in rats with diabetes mellitus using DPOAE and histopathological analysis.

\section{MATERIALS AND METHODS}

This study was carried out between 2016 Jannuary and 2017 January in accordance with the "10 International Principles for Animal Handling” and approved by the Istanbul University Istanbul Medical Faculty Animal Experiments Local Ethics Committee (Protocol no. 2014/112). The study included 18 male albino Sprague Dawley rats (weighing $\geq 350 \mathrm{~g}$, at least two months of age) with normal otoscopic examinations and DPOAE. Because of the protective effects of melanin and estrogen, male albino rats were chosen. Animals were divided into three groups as the control group (group 1), STZ-induced diabetes group (group 2), and STZ-induced diabetes+HBOT group (group 3). The rats had normal DPOAE. Rats with narrow ear canals, otitis and ear wax that could have hindered the placement of an auditory probe were excluded. Rats were weighed once a week to monitor uncontrolled weight loss. Streptozocin (Zanosar, Sicor Pharmaceuticals, Irvine, CA, USA) was administered intraperitoneally using a single injection at a dose of $60 \mathrm{mg} / \mathrm{kg}$. Tail blood was monitored before STZ administration, three days after STZ injection and every 15 days after injection. Hyperglycemia, defined as the eight-hour fasting blood glucose (FBG) level $>250 \mathrm{mg} / \mathrm{dL}$, was checked $12 \mathrm{~h}$ after STZ injection.

Intramuscular ketamine hydrochloride $(50 \mathrm{mg} / \mathrm{kg})$ (Ketalar, Zentiva Health Products, Pfizer, Kirklareli, Turkey) and xylazine (5 mg/kg) (Rompun, Bayer, Leverkusen, Germany) were administered as anesthesia prior to DPOAE measurements. ${ }^{[15]}$ Distortion product otoacoustic emissions was measured using the OTOsuite (GN Otometrics OTOsuite, Taastrup, Denmark; distribution release 4.73.02). Distortion product otoacoustic emissions measurements used the following frequencies: $2 \mathrm{~F}(1)-\mathrm{F}(2)$ at a ratio of $\mathrm{F}(2) / \mathrm{F}(1)=1.22$. For DPOAE measurements, the intensities of the primary stimuli were set at $\mathrm{L} 1 / \mathrm{L} 2=10 \mathrm{~dB}$ difference. Distortion product otoacoustic emissions were accepted 
as passing when the signal-to-noise ratio (SNR) was $\geq 6$. The noise floor was maintained at lower than 20 $\mathrm{dB}$ and SNRs were recorded at frequencies of 2,000$10,000 \mathrm{~Hz}{ }^{[16]}$ Distortion product otoacoustic emissions measurements were performed two times during the study: first, just before STZ injection and second, at the end of the eighth week, followed by decapitation.

Hyperbaric oxygen therapy was performed at the Department of Underwater and Hyperbaric Medicine in Istanbul University, Istanbul Faculty of Medicine. The total number of $\mathrm{HBO}_{2}$ sessions applied to group 3 was 14 , administered twice a day, for seven days a week during the sixth week of experiment. The treatments were conducted in a small research chamber $\left(0.4 \mathrm{~m}^{3}\right)$. The chamber was flushed with oxygen for $10 \mathrm{~min}$ to vent the air inside before compression, and thus the animals could be pressurized with $100 \%$ oxygen. The HBOT sessions consisted of $10 \mathrm{~min}$ of compression to 2 ATA, $60 \mathrm{~min}$ at $2 \mathrm{ATA}$ and $10 \mathrm{~min}$ of decompression.

Animals were decapitated under high doses of ketamine hydrochloride $(90 \mathrm{mg} / \mathrm{kg})+x y l a z i n e$
$(10 \mathrm{mg} / \mathrm{kg})$ anesthesia at the end of week eight. Posterior midsagittal craniotomy was performed and right and left temporal bullae were extracted. Tissues were fixed at formaldehyde. A blinded histologist evaluated the histopathologic specimens. For light microscopic examination, tympanic sections of the temporal bones were fixed in a solution of $10 \%$ formaldehyde at room temperature for $72 \mathrm{~h}$. For decalcification, specimens were stored in a solution of $10 \%$ formic acid (refreshed every two days) at $4^{\circ} \mathrm{C}$ for 12 days. The cochlea was separated from the temporal bones and split at the cochlear modiolus. All the specimens were dehydrated in an ethanol series and then embedded in paraffin wax. Paraffin-embedded specimens were cut into 5-6- $\mu \mathrm{m}$ thick sections, mounted on slides and stained with hematoxylin and eosin. ${ }^{[17]}$ Sections of tympanic bullae were examined using a Nikon Optiphot-2 light microscope and analyzed using the Nikon DS-L3 Image Analysis System (Nikon Corporation, Tokyo, Japan). Tissue alterations in each specimen were assessed in the organ of Corti, stria vascularis and spiral ganglia by an experienced histologist who was blinded to the

\begin{tabular}{|c|c|c|c|c|c|c|}
\hline \multicolumn{7}{|c|}{$\begin{array}{c}\text { Table } 1 \\
\text { Fasting blood glucose levels }\end{array}$} \\
\hline $\mathrm{FBG}(\mathrm{mg} / \mathrm{dL})$ & Pre STZ injection & $72^{\text {nd }}$ hour after STZ & $10^{\text {th }}$ day & $25^{\text {th }}$ day & $40^{\text {th }}$ day & $56^{\text {th }}$ day \\
\hline \multicolumn{7}{|l|}{ Group 1} \\
\hline 1 & 102 & 180 & 131 & 130 & 120 & 100 \\
\hline 2 & 67 & 190 & 92 & 140 & 140 & 120 \\
\hline 3 & 70 & 210 & 120 & 120 & 133 & 110 \\
\hline 4 & 69 & 100 & 129 & 134 & 125 & 132 \\
\hline 5 & 81 & 150 & 133 & 127 & 147 & 140 \\
\hline 6 & 88 & 160 & 200 & 125 & 132 & 90 \\
\hline \multicolumn{7}{|l|}{ Group 2} \\
\hline 1 & 142 & 248 & 392 & 260 & 300 & 320 \\
\hline 2 & 144 & 266 & 263 & 500 & 500 & 500 \\
\hline 3 & 100 & 290 & 200 & 240 & 460 & 400 \\
\hline 4 & 105 & 260 & 300 & 280 & 280 & 260 \\
\hline 5 & 90 & 316 & 248 & 260 & 280 & 300 \\
\hline 6 & 80 & 300 & 280 & 411 & 312 & 280 \\
\hline \multicolumn{7}{|l|}{ Group 3} \\
\hline 1 & 51 & 300 & 260 & 500 & 500 & 500 \\
\hline 2 & 191 & 290 & 490 & 300 & 234 & 308 \\
\hline 3 & 98 & 297 & 300 & 295 & 446 & 401 \\
\hline 4 & 102 & 300 & 260 & 500 & 500 & 500 \\
\hline 5 & 51 & 369 & 507 & 360 & 480 & 467 \\
\hline 6 & 86 & 541 & 280 & 290 & 265 & 270 \\
\hline
\end{tabular}


groups. Microscopic changes in the organ of Corti (degeneration and loss of cells) and stria vascularis (degeneration and epithelial damage) were noted and scored as absent (0), mild (1), moderate (2) or severe (3); total maximum score $=9$. The percentage of degenerated cells in the spiral ganglia was determined. ${ }^{[17]}$

\section{Statistical analysis}

Statistical analysis was performed using the SPSS version 16.0 software (SPSS Inc., Chicago, IL, USA). Kruskal-Wallis (Mann-Whitney U test) was used for the analysis of non-parametric data. $\mathrm{P}$ value $<0.05$ was accepted as significant.

\section{RESULTS}

The eight-hour FBG level increased to $>250 \mathrm{mg} / \mathrm{dL}$ within 12 hours after STZ injection. Blood glucose levels were measured in tail blood samples using the Accu-Check Performa Nano (Roche Diagnostics, Istanbul, Turkey). On second measurement day, because all measurements were higher compared to other measurements and even the control group had high

\begin{tabular}{|c|c|c|c|}
\hline \multicolumn{4}{|c|}{$\begin{array}{c}\text { Table } 2 \\
\text { Change in weights }\end{array}$} \\
\hline Weight (gram) & Initial & $25^{\text {th }}$ day & $56^{\text {th }}$ day \\
\hline \multicolumn{4}{|l|}{ Group 1} \\
\hline 1 & 350 & 360 & 380 \\
\hline 2 & 350 & 347 & 340 \\
\hline 3 & 360 & 365 & 330 \\
\hline 4 & 350 & 350 & 300 \\
\hline 5 & 360 & 356 & 370 \\
\hline 6 & 370 & 389 & 378 \\
\hline \multicolumn{4}{|l|}{ Group 2} \\
\hline 1 & 356 & 340 & 280 \\
\hline 2 & 350 & 325 & 190 \\
\hline 3 & 360 & 338 & 298 \\
\hline 4 & 380 & 330 & 269 \\
\hline 5 & 369 & 342 & 300 \\
\hline 6 & 386 & 320 & 280 \\
\hline \multicolumn{4}{|l|}{ Group 3} \\
\hline 1 & 395 & 280 & 196 \\
\hline 2 & 376 & 300 & 290 \\
\hline 3 & 350 & 295 & 280 \\
\hline 4 & 380 & 240 & 192 \\
\hline 5 & 350 & 300 & 290 \\
\hline 6 & 350 & 289 & 270 \\
\hline
\end{tabular}

blood glucose levels, the device was switched to Wellion for blood sugar testing (Med Trust, Marz, Austria). At the end of the experiment, animal 2 in group 2 and animals 1 and 4 in group 3 weighed $<200 \mathrm{~g}$ and their FBG levels reached $>500 \mathrm{mg} / \mathrm{dL}$ (Tables 1 and 2).

Initial DPOAE measurements did not show any difference between animals. All animals had normal hearing. Second DPOAE measurement was performed at the end of the eighth week. Then, all animals were decapitated.

A total of 1,000 DPOAE acquisitions were analyzed. There were no significant differences in SNR values at $4,000,8,000$ or $10,000 \mathrm{~Hz}(\mathrm{p}=0.446)$. A significant decrease was observed at $2,000 \mathrm{~Hz}$ for groups 2 and $3(\mathrm{p}=0.040)$. No difference was observed for $2,000 \mathrm{~Hz}$ between groups 2 and 3. Distortion product otoacoustic emissions for each group were presented in a frequency specific manner in Table 3. Distortion product otoacoustic emissions levels at $8,000 \mathrm{~Hz}$ did not differ between the groups and remained high.

Histological evaluation of the control group revealed normal structures in the organ of Corti (Figure 1a), stria vascularis (Figure 1b) and spiral ganglia (Figure 1c). Sections from animals in group 2 showed histopathological alterations, including hydropic degeneration, loss of supporting and hair cells in the organ of Corti, deformation and thickening of the basilar membrane in the organ of Corti and fibrinoid material in the scala media (Figure 2a). Neuronal degeneration and neuronal loss were observed in group 2, along with increased eosinophilic staining in neuronal cytoplasms, nuclear condensation, eccentric nuclear placement, and pyknosis and edema in stria vascularis (Figure 2b). Epithelial degeneration, damage and vacuolization were detected in the spiral ganglion (Figure 2c). In group 3, histopathological damage was markedly reduced in the organ of Corti (Figure 3a), stria vascularis (Figure 3b) and spiral ganglion (Figure 3c).

Histological findings for each group were presented in Table 4. Spiral ganglia in group 2 had higher levels of edema compared with the other two groups $(p=0.001)$. Edema was not detected in the control group. There was more epithelial damage in the stria vascularis of group 2 compared with that of the other two groups $(p=0.001)$, while no epithelial damage was observed in the control group. There was greater degeneration of the organ of Corti in group 2 compared with that in the other groups. Degeneration in the organ of Corti was significantly reduced in group $3(\mathrm{p}=0.001)$. The total damage score was significantly higher in group 2 , lower in group 3 , and still lower in the control group $(\mathrm{p}=0.000)$. 

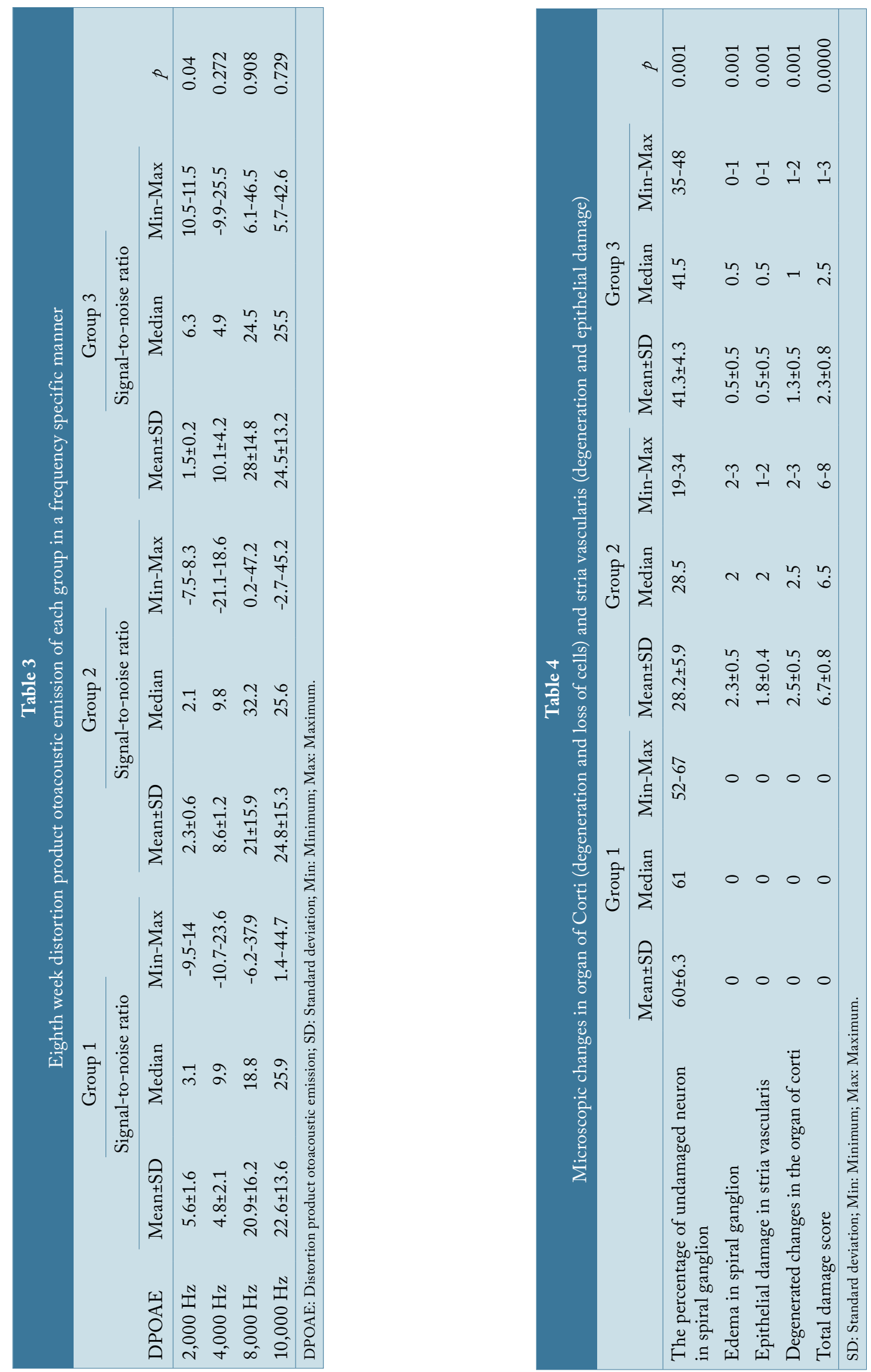

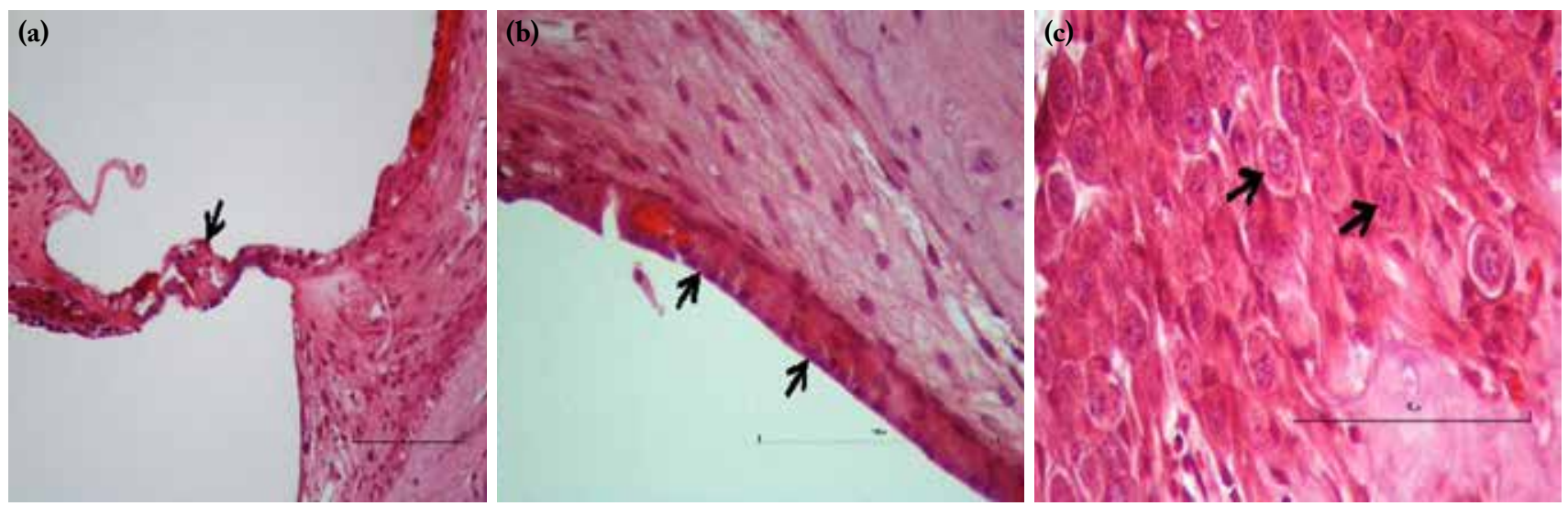

Figure 1. Hematoxylin and eosin staining of control group. (a) Organ of Corti (arrow), 20x; (b) stria vascularis (arrow), 40× and (c) neurons of spiral ganglion (arrow) 40x.
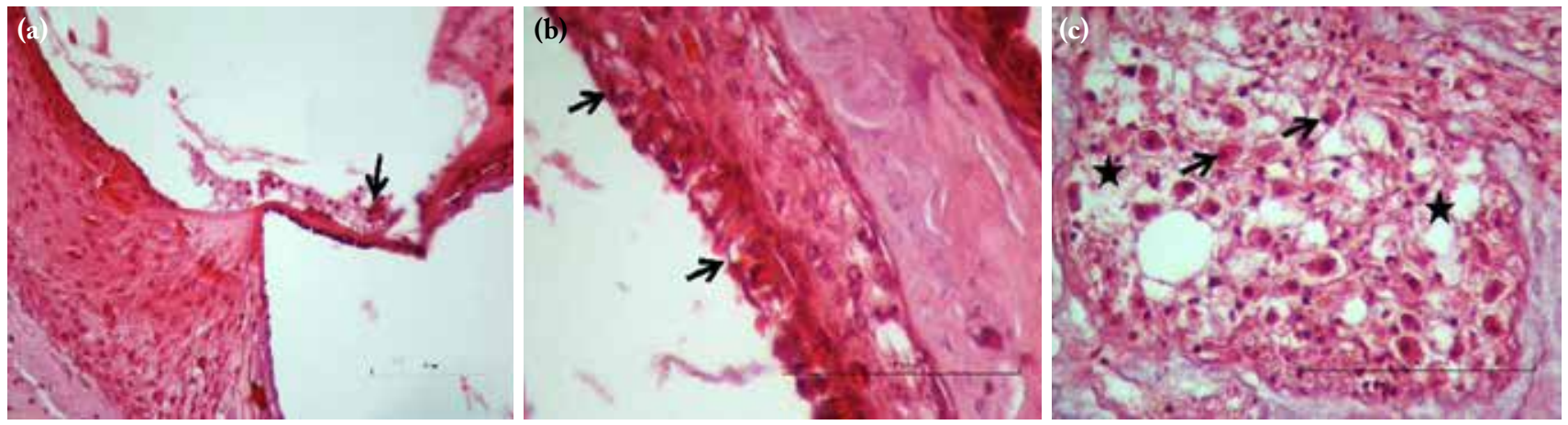

Figure 2. Hematoxylin and eosin staining of tissues from diabetic mouse model. (a) Organ of Corti (arrow), 20×; (b) stria vascularis (arrow), $40 \times$ and (c) neurons of spiral ganglion (arrow), edema (asterisk), 40×.
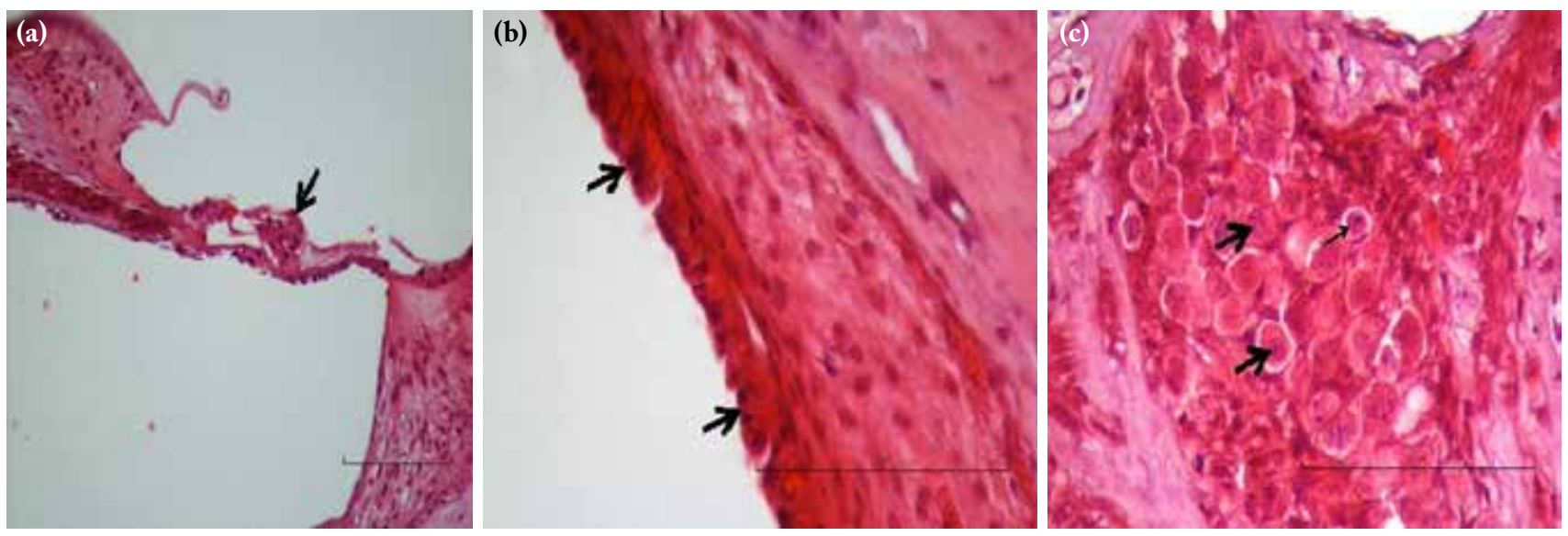

Figure 3. Hematoxylin and eosin staining of hyperbaric oxygen treated mice tissues. (a) Organ of Corti (arrow), 20×; (b) stria vascularis (arrow), 40x and (c) neurons of spiral ganglion (thick arrow), pyknotic neuron (thin arrow), 40x. 


\section{DISCUSSION}

Multiple types of hearing loss have been reported in diabetic patients, and bilateral sensorineural hearing loss, which affects hearing at high frequencies, is common. Diabetics have abnormal otoacoustic emissions, which indicate outer hair cell damage at the cochlear level. Complications due to hyperglycemia are dependent on the duration and level of hyperglycemia.

In the present study, we tested DPOAE to confirm that all animals initially had healthy hearing. Diabetes was induced by intraperitoneal injection of STZ, a commonly used diabetogenic drug that damages insulin-secreting pancreatic beta cells. The duration and level of hyperglycemia were the main parameters used to determine the level of tissue damage. To confirm that diabetic mice models were well established, we measured FBG levels. After hyperglycemia was detected, animals in group 3 were treated with $\mathrm{HBO}_{2}$ for one week at sixth week. At the end of week eight, DPOAE were recorded and animals were sacrificed.

In the literature, Tuk et al. ${ }^{[18]}$ treated the ulcers in diabetic rats with $\mathrm{HBO}_{2}$. The ulcers were formed four weeks after STZ injection. The authors observed a lasting improved tissue oxygenation after applying $\mathrm{HBO}_{2}$.

Sustained hyperglycemia results in dramatic weight loss in animal models. Therefore, we commenced our experiments using rats that weighed $\geq 350 \mathrm{~g}$. Nevertheless, we observed rapid weight loss in some animals. Thus, to prevent the uncontrolled loss of animals, we revised the protocol such that the experiments ended at the end of week eight.

There were no significant differences in SNR between the two groups at $4,000,8,000$ or $10,000 \mathrm{~Hz}$. However, at 2,000 Hz, there was a significant decrease in groups 2 and $3(\mathrm{p}=0.040)$, which indicated that hyperglycemia decreases outer hair cell function at lower frequencies before any other frequency. Because there was no difference between groups 2 and 3 , we concluded that $\mathrm{HBO}_{2}$ did not ameliorate the electrophysiological damage caused by hyperglycemia that was mainly detected at $2,000 \mathrm{~Hz}$. There was no difference in DPOAE levels at $8,000 \mathrm{~Hz}$ between the groups, and they seemed to remain high in all groups.

We observed marked endothelial damage in the diabetic groups (groups 2 and 3), indicating that hyperglycemia damages cochlear microstructures, and $\mathrm{HBO}_{2}$ seemed to reverse these effects of hyperglycemia. Although damage scores in group 2 were higher than group 3, percentage of damaged neurons in spiral ganglion was higher in group 3 than group 2. This finding suggests that while epithelial structures have the potential to regenerate themselves with $\mathrm{HBO}_{2}$, neuronal structures fail to do so.

In the study of Tuk et al., ${ }^{[18]} \mathrm{HBO}_{2}$ improved oxygen saturation and increased hemoglobin in the microvasculature of wound areas in a diabetic rat model. Vasoconstriction is a well-described effect of $\mathrm{HBO}_{2}$, and mediated by the inactivation of nitric oxide by superoxide radicals. Although blood flow is decreased, oxygenation levels in tissues increase because of increased hemoglobin level in microvessels and oxygen saturation of hemoglobin. The mechanism of action of $\mathrm{HBO}_{2}$ occurs via increasing oxygen content in poorly vascularized areas, such as diabetic wounds. ${ }^{[19]}$

In addition to the direct effect on oxygen availability in tissues, it has been suggested that $\mathrm{HBO}_{2}$ promotes angiogenesis during wound healing by increasing the availability of wound growth factors, most importantly, vascular endothelial growth factor (VEGF). ${ }^{[20,21]}$

In the present study, damage to the stria vascularis in group 2 was higher than in group 3. Because the damaging effects of hyperglycemia occurred at the same time in both groups, the decreased damage observed in the stria vascularis may be attributed to the ameliorating effect of $\mathrm{HBO}_{2}$.

Sheikh et al. ${ }^{[22]}$ demonstrated increased VEGF levels in aspirates of fluid from surgical wounds in rats treated with $\mathrm{HBO}_{2}$ twice daily. These results support the protective and/or regenerative effects of $\mathrm{HBO}_{2}$ on vasculature.

Moreover, Yassuda et al. ${ }^{[23]}$ demonstrated that $\mathrm{HBO}_{2}$ was protective against the ototoxic effects of cisplatin, while Pinto and Lewis ${ }^{[24]}$ stated that $\mathrm{HBO}_{2}$ did not induce any anatomical or functional changes in the cochlea exposed to amikacin. Hyperbaric oxygen may not be effective in cases of hair cell damage.

Hyperbaric oxygen also increased the formation of reactive oxygen species (ROS), which are known to cause cellular damage via the oxidation of lipids, proteins and deoxyribonucleic acid. ${ }^{[25,26]}$ Therefore, the absence of an increase in DPOAE levels in the $\mathrm{HBO}_{2}$ treated group in the present study may be because of the effects of ROS on outer hair cells.

It is possible that an eight-week period was too early to determine the electrophysiological effects of hyperglycemia on the inner ear by measuring DPOAE, although obvious histological damage was observed at the cochlear level.

The present study lacks the biochemical evidence to demonstrate that damage was induced by ROS. 
Nevertheless, histological changes clearly indicated that damage occurred in the hyperglycemia group and that $\mathrm{HBO}_{2}$ had healing effects at the vascular level, although we were unable to demonstrate these changes using objective methods. The discord between the histological and electrophysiological findings may be because of the absence of high frequency DPOAE, which is a limitation of this study. In addition, biochemical markers should be used to observe the effects of $\mathrm{HBO}_{2}$ at the cochlear level. However, sampling cochlear fluid is difficult. Therefore, tail blood may be used to monitor ROS levels, which generally differ from those in tissue. Finally, weight loss in animal models is a major limitation of this study. We hypothesize that if animals could survive a longer period of hyperglycemia, it would be possible to objectively determine changes induced by hyperglycemia.

In conclusion, further studies using high frequency DPOAE and biochemical testing are necessary for a comprehensive evaluation of the effects of hyperglycemia on the inner ear. If proper algorithm can be formed, in light of our data in favor of $\mathrm{HBO}_{2}$ in diabetic cochlear degeneration, we believe that management of hearing loss in diabetics may evolve dramatically.

- Hazardous effects of hyperglycemia can be observed histologically at eighth week, even in the absence of DPOAE changes.

- Hyperglycemia induces degeneration and loss of cells in the organ of Corti and epithelial damage in stria vascularis.

- Damages caused by hyperglycemia were all partially reversed by a brief $\mathrm{HBO}_{2}$ therapy.

- Difference between histologic scores of damage was significant between $\mathrm{HBO}_{2}$ group and study group in favor of the promising healing effects of $\mathrm{HBO}_{2}$.

\section{Declaration of conflicting interests}

The authors declared no conflicts of interest with respect to the authorship and/or publication of this article.

\section{Funding}

The authors received no financial support for the research and/or authorship of this article.

\section{REFERENCES}

1. Health Quality Ontario. Hyperbaric Oxygen Therapy for Non-Healing Ulcers in Diabetes Mellitus An EvidenceBased Analysis. Ontario Health Technology Assessment Series 2005;5:1-28.
2. Jabbari Moghaddam Y. Acoustic emissions from the inner ear and brain stem responses in type 2 diabetics. Int J Gen Med 2011;4:871-4.

3. Fukushima H, Cureoglu S, Schachern PA, Paparella MM, Harada T, Oktay MF. Effects of type 2 diabetes mellitus on cochlear structure in humans. Arch Otolaryngol Head Neck Surg 2006;132:934-8.

4. Mangabeira Albernaz PL, Fukuda Y. Glucose, insulin and inner ear pathology. Acta Otolaryngol 1984;97:496-501.

5. Brands AM, Biessels GJ, de Haan EH, Kappelle LJ, Kessels RP. The effects of type 1 diabetes on cognitive performance: a meta-analysis. Diabetes Care 2005;28:726-35.

6. Guinan JJ Jr, Salt A, Cheatham MA. Progress in cochlear physiology after Békésy. Hear Res 2012;293:12-20.

7. Sockalingam R, Freeman S, Cherny TL, Sohmer H. Effect of high-dose cisplatin on auditory brainstem responses and otoacoustic emissions in laboratory animals. Am J Otol 2000;21:521-7.

8. Doyle KJ, McLaren CE, Shanks JE, Galus CM, Meyskens FL. Effects of difluoromethylornithine chemoprevention on audiometry thresholds and otoacoustic emissions. Arch Otolaryngol Head Neck Surg 2001;127:553-8.

9. Simoncelli C, Ricci G, Molini E, Scionti L, Giommetti S, Pennacchi A, et al. Evoked acoustic oto-emissions in patients with diabetes mellitus. Ann Otolaryngol Chir Cervicofac 1993;110:255-8.

10. Lee HS, Kim KR, Chung WH, Cho YS, Hong SH. Early sensorineural hearing loss in ob/ob mouse, an animal model of type 2 diabetes. Clin Exp Otorhinolaryngol 2008;1:211-6.

11. Manna P, Sinha M, Sil PC. Protective role of arjunolic acid in response to streptozotocin-induced type-I diabetes via the mitochondrial dependent and independent pathways. Toxicology 2009;257:53-63.

12. Körpinar S, Alkan Z, Yiğit O, Gör AP, Toklu AS, Cakir B, et al. Factors influencing the outcome of idiopathic sudden sensorineural hearing loss treated with hyperbaric oxygen therapy. Eur Arch Otorhinolaryngol 2011;268:41-7.

13. Matsunami T, Sato Y, Sato T, Ariga S, Shimomura T, Yukawa M. Oxidative stress and gene expression of antioxidant enzymes in the streptozotocin-induced diabetic rats under hyperbaric oxygen exposure. Int J Clin Exp Pathol 2009;3:177-88.

14. Weaver LK, editor. Undersea and hyperbaric medical society hyperbaric oxygen committee, hyperbaric oxygen therapy indications the hyperbaric oxygen therapy committee report. In: Idiopathic Sensorineural Hearing Loss. 13th ed. Florida. Best Publishing Company; 2014. p. 139-53.

15. Koçak HE, Taşkın Ü, Aydın S, Oktay MF, Altınay S, Çelik DS, et al. Effects of ozone (O3) therapy on cisplatininduced ototoxicity in rats. Eur Arch Otorhinolaryngol 2016;273:4153-9.

16. Maia FC, Lavinsky L, Möllerke RO, Duarte ME, Pereira DP, Maia JE. Distortion product otoacoustic emissions in sheep before and after hyperinsulinemia induction. Braz J Otorhinolaryngol 2008;74:181-7.

17. Karaer I, Simsek G, Gul M, Bahar L, Gürocak S, Parlakpinar H, et al. Melatonin protects inner ear against radiation damage in rats. Laryngoscope 2015;125:345-9. 
18. Tuk B, Tong M, Fijneman EM, van Neck JW. Hyperbaric oxygen therapy to treat diabetes impaired wound healing in rats. PLoS One 2014;9:e108533.

19. Niinikoski JH. Clinical hyperbaric oxygen therapy, wound perfusion, and transcutaneous oximetry. World J Surg 2004;28:307-11.

20. Calvert JW, Cahill J, Zhang JH. Hyperbaric oxygen and cerebral physiology. Neurol Res 2007;29:132-41.

21. Thom SR. Oxidative stress is fundamental to hyperbaric oxygen therapy. J Appl Physiol (1985) 2009;106:988-95.

22. Sheikh AY, Gibson JJ, Rollins MD, Hopf HW, Hussain $Z$, Hunt TK. Effect of hyperoxia on vascular endothelial growth factor levels in a wound model. Arch Surg 2000;135:1293-7.
23. Yassuda CC, Righetti AE, Cury MC, Hyppolito MA, Oliveira JA, Féres $\mathrm{O}$. The role of hyperbaric oxygen therapy (hot) as an otoprotection agent against cisplatin ototoxicity. Acta Cir Bras 2008;23:72-6.

24. Pinto VS, Lewis DR. Distortion product otoacoustic emissions in infants from birth to two months. Pro Fono 2007;19:195-204.

25. Speit G, Dennog C, Radermacher P, Rothfuss A. Genotoxicity of hyperbaric oxygen. Mutat Res 2002;512:111-9.

26. Amora Lde A, Murashima Ade A, Rossato M, Moreira MB, Hyppolito MÂ, Fagundes DJ. The effects of hyperbaric oxygen therapy upon ototoxic injuries produced by amikacin in guinea pigs. Braz J Otorhinolaryngol 2013;79:342-8. 